\title{
WZB
}

Berlin Social Science Center

\section{Transition Spillovers? The Protest Behaviour of the 1989 Generation in Europe}

Philippe Joly

Preprint

February 2019

Recommended citation:

Joly, P. (2019). Transition Spillovers? The Protest Behaviour of the 1989 Generation in Europe. SocArXiv. https://doi.org/10.31235/osf.io/kcuws 


\section{Affiliations of the author}

Philippe Joly

Department of Democracy and Democratization

WZB Berlin Social Science Center

Reichpietschufer 50

10785 Berlin

Germany

Berlin Graduate School of Social Sciences

Humboldt-Universität zu Berlin

Unter den Linden 6

10099 Berlin

Germany

Email: jolyphil@hu-berlin.de

ORCID: https://orcid.org/0000-0002-4278-9439

\section{Copyright}

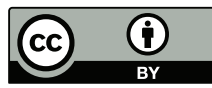

()2019 Philippe Joly. This is an open access paper (pre-peer reviewed) distributed under the terms of the CC-BY License. Preprints facilitate the diffusion of early research findings and allow authors to engage with a broad community of scholars. 


\begin{abstract}
Many studies suggest that citizens of Central and Eastern Europe are less politically active than their peers in Western Europe. Yet, it is unclear whether previous experiences of mobilization moderate these differences. This article focuses on the protest behaviour of the 1989 generation, which is composed of citizens who reached political maturity during the collapse of communism. Building on political socialization theory, the article proposes that citizens exposed to high levels of protest during their formative years might be more inclined to protest later. This implies that mobilization during the transitions from communism might moderate the current East-West gap in participation. The article combines data from 25 new and old democracies to assess how early exposure to protest has affected the participation of the 1989 generation. The results of multilevel models indicate that participation in demonstrations is not significantly lower in Central and Eastern Europe once we account for the level of protest at the turn of the nineties. Furthermore, the Eastern deficit in participation in petitions and boycotts is lower in societies that experienced higher levels of protest during the collapse of communism. Some results, however, are sensitive to the inclusion of Eastern Germany, an influential case.
\end{abstract}

Keywords: protest; political participation; political socialization; generations; democratization; post-communism; legacies

\title{
Acknowledgements
}

I thank Bernhard Weßels and my colleagues from the Department of Democracy and Democratization at the WZB Berlin Social Science Center for very useful comments and suggestions. This study would not have been possible without the financial support of the Fonds de recherche du Québec - Société et culture (FRQSC) and the Fellowship Freies Wissen, sponsored by Wikimedia Deutschland, the Stifterverband and the Volkswagen Foundation.

\section{Reproducibility}

Documentation and materials to reproduce the findings of this study are openly available on Zenodo at https://doi.org/10.5281/zenodo.2563207, version v1.1. 


\section{Introduction}

Since the beginning of the 2000s, many studies have found that political participation is lower among citizens of new democracies in Central and Eastern Europe than in the older democracies of Western Europe. Data from cross-national surveys indicate that this participation gap extends to both electoral and non-electoral forms of political involvement (Bernhagen \& Marsh, 2007; Hooghe \& Quintelier, 2014; Inglehart \& Catterberg, 2002; Kostelka, 2014). These findings contrast with the mass mobilization observed during the collapse of communist regimes at the turn of the nineties. In many countries of Central and Eastern Europe, the democratic breakthroughs were fuelled by large social movements. To many observers at the time, the transitions from communism were a clear demonstration that "people power" matters in democratization (Bunce \& Wolchik, 2011; Teorell, 2010). This leaves scholars to wonder what remains of the transitional mobilization in post-communist Europe. Or, in the words of Donatella della Porta, "where did the revolution go?” (della Porta, 2016).

Surprisingly, little research has tried to connect the current state of political participation in Central and Eastern Europe with experiences of mobilization during the transition. Crossnational studies have usually explained differences in participation levels between old and new democracies in Europe with reference to opportunity structures and collective resources (Dalton, van Sickle, \& Weldon, 2010; Vráblíková, 2014); otherwise they suggest that the very nature of communist regimes produced apathetic citizens (Howard, 2003; Pop-Eleches \& Tucker, 2013). The literature has not closely looked at the effect of legacies of transition on political involvement after the establishment of democracy.

This paper re-examines current differences in political participation between new and old democracies of Europe and explores how these differences are moderated by previous experiences of mobilization. The empirical strategy exploits the facts that 1) the mobilization that accompanied the transition from communism in Central and Eastern Europe occurred approximately at the same time in different countries, but 2) the share of the population involved in these protests varied a lot across countries. This means that citizens of the same generation experienced different types of transitions to democracy: some were exposed to high levels of mobilization in some countries, others to low levels.

I focus on the protest behaviour of the "1989 generation," that is, the group of citizens who were aged 17 to 25 in 1989. According to theories of political socialization, political events impact the young in society first and foremost (Mannheim, 1952). The period from mid-adolescence to early adulthood is considered crucial for the formation of political identities and the development political habits (Bartels \& Jackman, 2014; Neundorf \& Smets, 2017). The 1989 generation includes citizens who were at the peak of their political sensitivity when the wave of democratization broke in Central and Eastern Europe. I hypothesize that citizens of the 1989 generation who were exposed to a higher mobilization have tended to participate more later in their life. I expect 
that some transitions in Central and Eastern Europe have had a spillover effect that moderates the current East-West participation gap.

To test this hypothesis, two types of data are necessary: data on the level of mobilization during the transition from communism and data on current political participation. Here, the second wave of the European Values Study (1990-93) gives a snapshot of the level of mobilization during or directly after the transitions in Central and Eastern Europe whereas the European Social Survey tracks the development of political participation from 2002 to 2017. I compare the protest trajectory of the 1989 generation in 10 post-communist and 15 West European democracies over the 16 years covered by the ESS.

The analysis focuses on protest rather than on electoral forms of political participation, as this type of political involvement is more closely connected to the mobilization during the transitions. I look at three forms of protest separately: taking part in lawful demonstrations, signing petitions, and boycotting certain products. Multilevel models allow me to disentangle the effects of individual, country-variant, and country-invariant factors behind the participation in these activities. The paper is structured as followed. First, I review the literature on the East-West participation gap. Second, I discuss the theories of legacies of transition. Third, I look at the context in which the 1989 generation reached political maturity in countries of the former Eastern bloc and formulate theoretical expectations as to the development of protest in the years since the transition from communism. Fourth, I explain my empirical strategy. Fifth, I present the results of the multilevel analysis and, sixth, I summarize the findings and discuss their implications for future research on civil society in post-communist democracies.

\section{The East-West Participation Gap}

How is the mobilization during the transition from communism reflected in current levels of political participation in Central and Eastern Europe and how does it moderate the East-West participation gap? According to the dominant perspective in the literature, the effect of the mobilization during the transition rapidly faded during the nineties. Since then, inter-regional differences in political participation, between old and new democracies in Europe, appear to have trumped intra-regional diversity. The lack of political involvement in the post-communist region seems to reflect the shared experience state-socialism and structural adjustments after the transition.

According to many authors, the domination of communist parties over civil society organizations and the lack of mobilizing networks after the transition explain why, nowadays, citizens of Central and Eastern Europe tend to be less politically engaged. Communist regimes actively sought to encourage participation by their citizens. Yet, political involvement was usually channelled through top-down organizations and used to legitimate the system. Autonomous, contentious participation, in contrast, was discouraged and often repressed. After the transition, the 
communist "transmission belts" between citizens and the state were rapidly dismantled, leaving only a few independent groups to aggregate and organize citizens' demands (Barnes, 2006). Friendship networks appear to have partially substituted for formal civil society organizations (Howard, 2003). Yet these private relationships are less likely to stimulate political involvement at a large scale. Beyond leaving a weak mobilizing infrastructure, communist regimes affected the "demand-side" of political involvement. Pop-Eleches and Tucker find that the length and intensity of individual exposure to communism explains differences in participation in civil society organizations (Pop-Eleches \& Tucker, 2013). This legacy of political socialization is also reflected in low trust in political parties (Pop-Eleches \& Tucker, 2011), which correlates with apathy and low levels of external efficacy (Rose, 1995).

Furthermore, scholars highlight the role played by the difficult economic and political reforms in the demobilization of post-communist citizens. After the euphoria of 1989-91, the double transition to democracy and market economy was felt hard in Central and Eastern Europe. High unemployment rates, low income, and, rising inequalities led to "a sharp contraction of political action" (Inglehart \& Catterberg, 2002, 314). Following a pattern observed in other third-wave democracies, voter turnout declined during democratic consolidation (Kostadinova $\&$ Power, 2007). In the post-communist region, this drop in electoral participation was coupled with unstable party systems (Rose, 1995). Political elites often appeared incapable of fulfilling the high expectations of citizens and were sanctioned severely in the polls. High electoral volatility, in turn, weakened partisan ties, which usually foster mobilization. The problems of corruption and bad governance that persisted in the two decades after the transition further depressed political participation (Hooghe \& Quintelier, 2014).

Overall, post-communist citizens appear to face a distinct set of obstacles to participation. Yet, this emphasis on a common post-communist "syndrome" tends to neglect the remarkable diversity of exits from communism. Given that the transitions to democracy in Central and Eastern brought hundreds of thousands of citizens onto the streets, it would be surprising if the mobilization did not influence political involvement in the following years. If this were the case, the East-West participation gap could be moderated - at least in some countries - by previous experiences of mobilization during the transition.

\section{The Legacies of Transition: Three Mechanisms}

The research on democratization and social movements highlights three mechanisms through which bottom-up transitions can have a positive impact on political involvement. First, at the institutional level, some authors argue that democracies born out of nonviolent campaigns tend to be more inclusive and, therefore, more receptive to the demands of civil society. In their seminal study on civil resistance, Chenoweth and Stephan find that nonviolent campaigns are more successful in achieving their goals than violent campaigns (Chenoweth \& Stephan, 2011). Fur- 
thermore, countries that went through episodes of non-violent as opposed to violent mobilization are more likely to become and remain democratic (Bayer, Bethke, \& Lambach, 2016). According to these studies, the main advantage of nonviolent campaigns is their appeal to broad segments of society. Nonviolent resistance campaigns gather large number of supporters. Once opponents to autocratic regimes obtain power, they are usually accountable to many parties and have to find compromises. This gives rise to a culture of dialog among the new political elites. As suggested by della Porta, "the political inclusivity is here higher, given the (institutional and cultural) imprinting by those civic society activists who entered political and administrative institutions in large numbers" (della Porta, 2016, 354). Former social movement activists in the political apparatus will probably perceive contestation as a normal and even expected part of the democratic consolidation process. By increasing the political acceptance of protest, bottom-up transitions might foster more active political participation.

Second, at the organizational level, the groups behind the transitional mobilization will likely share networks, resources, and strategies that can be reused for other causes once democracy has been established. Social movements are coalitions of organizations. At the end of a cycle of contention, these organizations might split and support different policy goals. In the process, they are likely to carry with them common "interpretive frames, organizational structures, political analysis, and tactics" (Meyer \& Whittier, 1994, 290). The diffusion of these ideas and practices may fuel other protests later. In the case of movements for democracy, mobilization usually involves a broad spectrum of organizations, which, in spite of their differences, decide to join forces to oust authoritarian rulers. While these transitional coalitions rarely survive the founding elections in new democracies, they can provide symbolic and organizational resources for further mobilization (della Porta, 2016, 346). In Slovakia, for example, Prime Minister Vladimír Mečiar and his party, the HZDS, were defeated during the 1998 parliamentary elections, putting an end to the illiberal turn taken by the young democracy since the independence. This electoral turnover was facilitated by coordination between many civil society organizations under the Civic Campaign (OK) '98. Symbols of the transition were re-appropriated by OK '98 activists and the leaders of the movement did not hesitate to describe their mobilization as a second or “delayed Velvet Revolution” (Bútora \& Bútorová, 1999).

Finally, at the individual level, exposure to and participation in mass protests during the transition might lead certain cohorts of citizens to develop a taste for political activism. From the literature on political socialization, we know that events experienced between mid-adolescence to early adulthood shape a person's political attitudes and habits (Bartels \& Jackman, 2014; Neundorf \& Smets, 2017). Political generations with distinct orientations emerge from early political experiences during these "impressionable years" (Mannheim, 1952). Social movement scholars have observed this pattern among activists of the New Left in the United States. A series of follow-up studies on young protesters involved in the civil rights, anti-war, and women's movements show that these activists continued to participate throughout their lives. Intense episodes 
of mobilization during the 1960s and 1970s set this generation of participants on a unique course of political engagement (Jennings, 1987; McAdam, 1999). At the level of national populations, the effect of political socialization on political activism was also observed in various studies that tracked generational differences in political participation using nationally representative survey data. In the United States, Caren and his collaborators found that Baby Boomers were more likely to have taken part in demonstrations than other cohorts, after controlling for age and period effects (Caren, Ghoshal, \& Ribas, 2011). Similarly, in Western Europe, Grasso showed that citizens who reached political maturity during the 1960s and 1970s were the most involved in non-institutionalized forms of political participation (Grasso, 2014). This literature suggests that the political context experienced by citizens at a young age might have an enduring effect on political engagement. Returning to Central and Eastern Europe, we might expect the "eventful" transitions in the region to have constituted defining socialization moments (della Porta, 2016, 346). Participation or simply exposure to massive, peaceful, and successful protest for democracy might have led young citizens to embrace non-institutionalized forms of political participation as an effective way of bringing about political change.

All three mechanisms presented here are likely to influence political participation in postcommunist European democracies. In this paper, I propose a research design that specifically targets the last mechanism. The socialization effect of transitional mobilization remains underresearched in the literature. Looking at the East German case, Joly has shown that the legacy of transitional mobilization was not enough to bridge the overall participation gap between in East and West Germans (Joly, 2018). Yet, for younger cohorts of the post-Cold war generation, this participation deficit was reduced for participation in petitions and boycotts. Building on these results, I extend the analysis to a broader sample of countries and follow the protests of young citizens who experienced the transitions: the 1989 generation. I compare protest participation of this generation in Central and Eastern Europe with protest participation by the same generation in Western Europe and explore how previous experiences of mobilization moderate the gap of political involvement between old and new democracies.

\section{The 1989 Generation: Different Experiences of Mobilization at the Turn of the nineties}

As previously discussed, the literature on political socialization suggests that the age from midadolescence to early adulthood - the "impressionable years" - is particularly important for the development of democratic citizenship. In this paper, I focus on the 1989 generation, which I define as citizens who were aged 17 to 25 years old in 1989, the year when the wave of democratization started in the Eastern bloc. The types of transition experienced by the young citizens of the 1989 generation varied a lot across countries.

In Eastern Germany and Czechoslovakia, the popular upsurge involved a large share of the 
population and prompted a rapid implosion of the communist regimes. The extrication from communism was swift and radical. There were also protests in Poland and Hungary, but the power transfers were negotiated and facilitated through round tables with opposition and communist leaders. In Bulgaria, members of the communist regime initiated a transition from above to prevent the formation of an effective opposition. In the Baltic states and in the Balkans, the collapse of communism was linked to the fight for national independence and involved at times violent confrontations (Ekiert, 2003).

Data from the second wave of the European Values Study, conducted between 1990 and 1993, allow me to get a good grasp on the various levels of protest experienced by citizens during or directly after the transitions in Central and Eastern Europe (EVS, 2015). In a series of questions on political participation, the EVS asked respondents whether they ever had taken part in a demonstration. Given their young age at that time, respondents of the 1989 generation necessarily linked this "ever" to the political context that directly preceded the survey, which, in post-communist democracies, corresponded to the last years of the communist regimes and the transitional period. Except for the Baltic states, all the selected Central and Eastern European cases achieved minimal standards of democratic rule before or during the year of the EVS fieldwork, according to data from Boix, Miller, and Rosato (2013) (see Table 1). Although Estonia, Latvia, and Lithuania did not constitute full democracies at the time, they nonetheless had started implementing important political reforms in the wake of the Singing Revolution.

- Table 1 here -

Figure 1 reports the proportion of respondents of the 1989 generation affirming that they had taken part in demonstration, in 25 European polities. Looking at these results, it seems quite clear that, at the turn of the nineties, there was no deficit in participation among the citizens of the 1989 generation in Central and Eastern Europe. In fact, the average proportion of citizens having taken part in a demonstration was higher in Central and Eastern Europe (0.28) than in Western Europe (0.23). What is striking is the variance between citizens of post-communist countries. The standard deviation in the sample of new democracies is particularly high at 0.16 compared to 0.09 for old democracies. While more than $60 \%$ of the respondents of East Germany from the 1989 generation said that they had taken part in a demonstration, less than $10 \%$ had done so in Slovenia and Hungary. This contrast appears to directly relate to the very different paths of extrication from communism taken by these countries.

- Figure 1 here -

Are these radically different experiences of mobilization during the transition reflected in current levels of participation? According to theories of political socialization, cohorts exposed to high levels of protest at a young age might be more inclined to participate later in their life. Therefore, in countries where mobilization was widespread, the transition might have had a 
spillover effect on protest in the following years. Two types of spillover effect are plausible. On the one hand, we might expect a positive and homogeneous effect of early exposure to protest across old and new democracies. As shown in Figure 2a, this means that societies that participated more in the past would continue to do so later. In this scenario, the East-West participation gap remains constant, independent of prior levels of protest $\left(H_{1}\right)$. On the other hand, the effect of early exposure to protest might have been more important for the 1989 generation in new democracies. In Central and Eastern Europe, cohorts that went through high levels of mobilization during the transition might have been able to compensate for the obstacles to participation faced by post-communist societies. In this case, East-West participation would be moderated by early exposure to protest, as shown in Figure $2 \mathrm{~b}\left(\mathrm{H}_{2}\right)$.

- Figure 2 here -

\section{Empirical Strategy}

\subsection{Data}

To test these hypotheses, this paper combines two types of data. First, to follow recent levels of protest in various European democracies, I rely on individual-level data collected over eight rounds of the European Social Survey (ESS), from 2002 to 2017 (ESS, 2017). Second, to get an estimation of the intensity of mobilization at the turn of the nineties, I use an aggregate measure obtained from the second wave of the European Values Study (EVS), conducted between 1990 and 1993 (EVS, 2015). 25 countries (including Eastern Germany as a country) participated in both the second wave of the EVS and at least one round of the ESS. All the countries in the sample, except Latvia, participated in at least three rounds of the ESS.

I limit the ESS sample to respondents from the 1989 generation, that is individuals born between 1964 (those who were aged 25 in 1989) and 1972 (those who were aged 17 in 1989). While some authors in the field of political socialization suggest that the early formative years begin at a lower age - possibly even during childhood (Bartels \& Jackman, 2014; Neundorf \& Smets, 2017) - the second wave of the EVS only targeted citizens who had reached the age of majority. Since this survey started in 1990, the youngest citizens for whom data is available were born in 1972. Beyond the constraints imposed by the survey data, the decision to limit the sample this way also makes sense from a theoretical point of view. Participation in protest demands more cognitive and physical capacities than does the development of attitudes, such as political interest or the formation of basic ideological orientations. It requires a high degree of autonomy, only reached at the end of adolescence. Therefore, it seems appropriate to define 17 years of age as a lower bound for the 1989 generation. This specification means that I can use the data to track members of the 1989 generation from the age of 30 to 39 in the first round of the ESS to the age of 44 to 53 in the eighth round. 


\subsection{Dependent Variables}

Over the 16 years covered by the study, the ESS asked respondents about their involvement in electoral and non-electoral forms of political participation. Three items measuring protest behaviour were incorporated in the core questionnaire. They asked respondents whether they had, during the 12 months preceding the survey, 1) attended a lawful demonstration, 2) signed a petition, or 3) boycotted certain products. These variables were coded as dichotomous. I apply separate models for the three forms of protest. One interesting avenue of research is to examine whether mobilization at the end of the 1980s and beginning of the nineties had a different spillover effect on more or less disruptive forms of protest.

\subsection{Old and New European Democracies}

The sample includes 10 new democracies (Bulgaria, Czech Republic, Estonia, Hungary, Eastern Germany, Latvia, Lithuania, Poland, Slovakia, and Slovenia) and 15 old democracies (Austria, Belgium, Denmark, Finland, France, Western Germany, Iceland, Ireland, Italy, the Netherlands, Norway, Portugal, Spain, Sweden, and the United Kingdom). The Spanish and Portuguese democracies are rather young to be classified as "old democracies," but, at the time when the 1989 generation reached political maturity, they were already securely engaged on the path of democratic consolidation. Teenagers and young adults in the selected West European democracies came of age in a much more stable and predictable political system than their peers in Central and Eastern Europe. Protest was already deeply rooted within the mechanics of democracy when they became old enough to get involved themselves. Their experience contrasts with the much more contentious and fluid context in which young post-communist citizens grew up.

\subsection{Early Exposure to Protest}

To measure the exposure to protest of citizens of the 1989 generation during their formative years, I created a variable that aggregates data at the country-level from the second wave of the EVS. This variable simply corresponds to the weighted proportion of respondents of the 1989 generation who affirmed, during the EVS fieldwork from 1990 to 1993, that they ever had taken part in a demonstration (as in Figure 1). This variable ranges from 0.07 (Hungary) to 0.61 (Eastern Germany). The country average is 0.25 .

\subsection{Control Variables}

Some factors have a direct effect on the resources available to citizens to join in protests and might be, if they were not controlled for, confounded with the effect of political socialization. Therefore, at the individual-level, the analysis controls for gender, age compared to the other members of the generation (from 1 to 9 years), education level (low, middle, or high), employment status 
(employed or unemployed), place of birth (native or not ${ }^{1}$ ), size of the town (from 1: "a farm or home in the countryside" to 5: "a big city"), and current or previous membership of a labour union (yes or no). In addition, I use Oesch's classification of occupations to sort respondents into five social classes (higher-grade service class, lower-grade service class, small business owners, skilled workers, and unskilled workers) (Oesch, 2006a, 2006b). The use of a relative instead of an absolute measure of age is justified because age is collinear with the year of the survey. A relative measure allows me to control for compositional differences within the 1989 generation in different countries.

At the macro-level, the limited number of higher-level units (25 countries and 163 countrywaves) restrains the number of controls that can be included. I opted to incorporate the countrymean and within country-difference of GDP per capita (constant 2010 USD, logged) and the year of the ESS (Arbeitskreis "Volkswirtschaftliche Gesamtrechnungen der Länder", 2018; World Bank, 2018). ${ }^{2}$ The average GDP per capita is a proxy of economic development that is known to foster protest participation, whereas the within-country variation of GDP can account for the impact of economic growth and recession on political participation. The year of the survey might capture both a linear period effect and the effect of the aging of the 1989 generation.

\subsection{Statistical Approach}

The results are based on three-level logistic models with random intercepts. Respondents are nested in country-waves, which are themselves clustered into countries. This specification allows me to disentangle the effects of individual, country variant, and country-invariant predictors of protest participation. Equation 1 describes the basic form of the models.

$$
\begin{gathered}
{\text { LogitPr }\left(\text { protest }_{i j k}\right)}=\beta_{0}+\beta_{1} \text { newdem }_{k}+\beta_{2} \text { earlyprotest }_{k} \\
+\beta_{3}(\text { newdem } \cdot \text { earlyprotest })_{k}+Z_{i j k}+\nu_{k}+v_{j k} \\
\text { with } \nu_{k} \sim \mathrm{N}\left(0, \sigma_{\nu}{ }^{2}\right) \text { and } v_{j k} \sim \mathrm{N}\left(0, \sigma_{v}{ }^{2}\right)
\end{gathered}
$$

Here, the logit of the probability of having taken part in a protest activity during the 12 months preceding the survey is a function of an overall intercept $\left(\beta_{0}\right)$, a dummy for new democracies $\left(\beta_{1}\right)$, the early exposure to protest as measured by the EVS between 1990 and $1993\left(\beta_{2}\right)$, the interaction of the two previous terms $\left(\beta_{3}\right)$, a vector of covariates at the three levels of analysis $\left(Z_{i j k}\right)$, the random effect of countries $\left(\nu_{k}\right)$, and the random effect of country-waves within countries $\left(v_{j k}\right)$. The inclusion of an interaction term allows me to test whether the gap of participation between citizens of new and old democracies remains constant $\left(H_{1}\right)$ or is moderated by previous exposure to mobilization $\left(H_{2}\right)$.

\footnotetext{
${ }^{1}$ For Eastern Germany, citizens born in Western Germany are also considered non-native.

${ }^{2} \mathrm{GDP}$ measures are adjusted for Eastern and Western Germany; see replication materials.
} 


\section{Findings}

I begin by descriptively examining whether the mobilization at the turn of the nineties has had a spillover effect on annual participation in protest activities between 2002 and 2017 in Europe. Figure 3 displays the proportion of citizens of the 1989 generation in 25 countries who had attended a lawful demonstration, signed a petition, or boycotted certain products in the year preceding each ESS round as a function of the protest level observed in the second wave of the EVS. The lines represent the linear fits for old and new democracies. Consistent with the literature, citizens of Central and Eastern Europe appear to participate less than citizens in Western Europe in all three forms of political participation. The East-West participation gap, however, varies depending on the type of protest and the level of mobilization measured at the beginning of the nineties. For demonstration attendance, the difference between old and new democracies remains constant, independent of previous levels of mobilization as expected in $H_{1}$. In contrast, the moderation hypothesis $\left(\mathrm{H}_{2}\right)$ appears to be supported for petition signing and participation in boycotts. For these two types of protest, the East-West participation gap is reduced for countries where protest was more widespread at the moment of the collapse of communism. This moderation effect is not only driven by a higher involvement in new democracies with more protest experience, but also, by a negative effect of early exposure to protest in old democracies. While, in Central and Eastern Europe, the measure of protest obtained from the second wave of the EVS appears to be positively correlated with recent involvement in petitions and boycotts, in Western Europe, there is no apparent diffusion across forms of political participation.

- Figure 3 here -

Tables 2 to 4 display the results of multilevel models applied to the three protest activities. Models 1, 4, and 7 include all the individual-level variables and three country-level variables: a dummy for new democracies, the level of protest experienced by the 1989 generation at the time of the EVS fieldwork, and the interaction of the two previous variables. This specification allows me to test the moderation hypothesis presented previously. If protest during the transitions in Central and Eastern Europe has had a spillover effect on the current political participation of the 1989 generation, we might expect the negative effect of new democracies to be reduced by previous exposure to protest.

$$
\begin{aligned}
& \text { - Table } 2 \text { here - } \\
& \text { - Table } 3 \text { here - } \\
& \text { - Table } 4 \text { here - }
\end{aligned}
$$

The results of these first multilevel models largely reflect the patterns observed in the bivariate graphs. For participation in demonstrations, the inclusion of the interaction term renders the effect of new democracies insignificant. The only macro-level factor that remains significant is 
early exposure to protest. This means that citizens in countries where protest was widespread at the time of the EVS fieldwork continue to participate more later and at a similar rate in both old and new democracies. Participation in petitions and boycotts, however, appears to follow a different pattern. Here, the effect of new democracies continues to be negative and significant, but it is moderated by the level of protest measured by the EVS. These results are in line with the moderation hypothesis $\left(H_{2}\right)$.

The effects of individual-level variables are consistent with findings in the literature on political participation and remain mostly unchanged with the inclusion of additional macro-level variables. Women are more likely than men to sign petitions and join boycotts but are less involved in demonstrations. Education, which fosters the development of civic skills, is positively related to all forms of protest. The effect of unemployment is not significant at the 0.05 level. In contrast, current or former membership of a union is a clear predictor of protest participation. Union members are apparently more informed and better networked to take part in contentious forms of political participation. Native citizens tend to be more involved in petitions and boycotts, most probably because they have access to more resources and are better integrated into participation networks. Individuals in big cities also seem to benefit from more effective mobilization structures. Finally, the effect of social classes varies across political actions. In general, members of the service classes are more likely to mobilize are more mobilized than small business owners and workers. The only exception is with boycotts. For this type of political participation, small business owners are also quite active.

When using a sample of 25 higher-level units, there is a risk that the effects observed may be driven by an outlier. Eastern Germany is the only case for which more than half of the respondents of the 1989 Generation had taken part in a demonstration at the time of the second wave of the EVS. As reported in the bivariate graphs in Figure 3, this higher-level unit might artificially increase the effect of previous mobilization on annual protest participation in new democracies. To control for the influence of Eastern Germany, Models 2, 5, and 8 include an additional dummy for this special case (Van der Meer, Grotenhuis, \& Pelzer, 2010). When it comes to participation in demonstrations, the effect of early exposure to protest remains unchanged when this additional variable is included. Differences between old and new democracies and the interaction with the level of mobilization in 1990-1993 continue to be statistically insignificant. For participation in petitions and boycotts, controlling for the influence of Eastern Germany depresses and renders insignificant the coefficient of the interaction between the indicator of new democracies and the level of protest at the beginning of the nineties. These findings only leave weak support for the moderation hypothesis.

- Figure 4 here -

The country-mean and within-country difference of GDP per capita together with the year of the survey are added as macro-level controls in Models 3, 6, and 9. These predictors are all 
insignificant at the 0.05 level, except the effect of the year on participation in boycotts. In the full models, the effect of new democracies becomes insignificant at the 0.05 level for participation in boycotts, but remains significantly negative for petition signing. The interaction term also remains statistically insignificant. Only for demonstration attendance do we see an enduring effect of previous mobilization. Based on these models, Figure 4 reports the predicted probabilities of having attended a lawful demonstration, signed a petition, and joined in boycotts during the year preceding the survey as a function of the level of protest measured at the turn of the nineties. Looking at demonstration attendance, the predicted probabilities are similar for old and new democracies at low levels of early exposure to protest, but diverge at high levels. The spillover effect of previous mobilization appears stronger in old democracies, in opposition with the moderation hypothesis. For participation in petitions and boycotts, the two groups of countries converge at higher levels of early exposure to protest. However, full convergence is only attained at levels of previous mobilization beyond those experienced by most countries in the sample. All in all, once the influence of Eastern Germany is controlled for, the results do not confirm that the participation gap between old and new democracies is attenuated by previous experiences of mobilization.

\section{Discussion and Conclusions}

Fifteen years ago, in what is probably the most cited publication on civil society in Central and Eastern Europe, Howard affirmed that "postcommunist civil society is distinctively weak" (Howard, 2003, 1). Since then, this claim has been echoed by many studies showing that citizens in new democracies of Europe are less politically active than citizens in old democracies. This paper has offered a new perspective on the East-West participation gap in Europe by looking at how experiences of mobilization at the time of the collapse of communism have affected political involvement in new and old democracies since the beginning of the 2000s. Inspired by theories of political socialization, I expected that citizens who were exposed to high levels of protest during their formative years might be more inclined to protest later in their life. I examined the protest behaviour of the 1989 generation, the cohort of citizens who were aged 17 to 25 in 1989. As older teenagers and young adults, these citizens witnessed different types of mobilization in their respective countries. In Central and Eastern Europe, some observed how the "people power" could successfully put an end to decades of autocracy; others were confronted with more top-down political changes.

To connect the current state of political participation of the 1989 generation with experiences of mobilization during the transition, I combined data from the European Values Study and the European Social Survey. The second wave of the EVS, conducted just after the start of the democratization movement in the Eastern bloc, gave an overview of the mobilization of young citizens at that time in different countries. The eight rounds of the ESS, from 2002 to 2017, allowed me to 
follow the participation of the 1989 generation as it advanced in age.

The analysis revealed that, at the aggregate level, the protest participation of the 1989 generation in Europe followed two distinct patterns, depending on the form of political participation. On the one hand, annual participation in demonstrations was correlated with the level of protest experienced by the 1989 generation during its formative years, both in old and new democracies. The participation gap between the two groups of countries was small and remained constant independent of previous levels of mobilization. These results were in line with the "constant gap" hypothesis $\left(H_{1}\right)$. On the other hand, mobilization at the turn of the nineties appeared to have had a stronger spillover effect on petition signing and participation in boycotts for citizens of Central and Eastern European countries. For these two types of protest, the participation deficit in new democracies appeared to be offset in societies that went through intense periods of mobilization during the transition from communism, therefore supporting the "moderation" hypothesis $\left(\mathrm{H}_{2}\right)$. These two patterns were again observed in parsimonious multilevel models. The analysis revealed a slightly different picture after including additional explanatory variables and, importantly, after controlling for the influence of Eastern Germany. For demonstration attendance, the effect of new democracies was not significant and early exposure to protest continued to be the best macro-level predictor of current participation. For petition signing and participation in boycotts, the moderation effect of previous mobilization on the East-West participation gap continued to be high and positive but lost statistical significance. Overall, I could not confirm that the East-West participation gap is reduced among citizens of the 1989 generation socialized during periods of high mobilization.

Why was Eastern Germany an influential case in the analysis and what can be learned from it? Eastern Germany had the particularity of combining a widespread mobilization during the transition from communism with the rapid adoption of a stable mobilizing infrastructure afterwards. While the democratic breakthrough in the German Democratic Republic was mainly driven by internal forces, the reunification process was largely dominated by Western Germany. In a matter of few months, East Germans inherited stable democratic institutions, a mature party system, and a large network of established civil society organizations. While older East German citizens might have still struggled to adjust to the new system (Joly, 2018), for young citizens at the time, this meant that the positive experience of the transition could rapidly be translated into day-to-day participation. In other post-communist societies with more fragile democratic institutions and a less consolidated social movement sector, the positive legacy of engagement left by the transition might not have achieved its full potential. Demand for participation might be comparable to demand in East Germany, but it remained latent without the resources necessary to turn the appeal to protest into action.

Some limitations of the study have to be taken into consideration. First, the analysis relies on cross-sectional data. The models cannot track participation of the same respondents over time as would be the case with panel data. Instead, I use repeated measures at the group level. 
Relevant questions, such as those on the long-term effect of individual participation, cannot be answered with the current research design. Second, the limited number of countries in the sample (especially new democracies) makes it difficult to disentangle macro-level factors of participation that are correlated with each other. Finally, the EVS fieldwork from 1990 to 1993 was done at different phases of the democratization sequence in different countries. When the survey was conducted, some countries were firmly on the path of democratic consolidation; others, like the Baltic states would need more time to become independent and stabilize their democracies. These differences mean that the aggregate measure of protest derived from the EVS might not fully capture the mobilization during the transition. Some of these concerns might be addressed by extending the set cases to other post-communist democracies and by combining the EVS data with other sources, for example, reports of protest events in newspaper articles.

The paper leads to additional questions: what caused the mobilization for democracy in the first place and could these causes still affect protest in post-communist Europe? Looking at democratic trajectories in Central and Eastern Europe, the literature suggests that different layers of legacies come into play: the level of modernization and democracy before the imposition of communist regimes, the types of socialist institutions during the regime, and the paths of extrication from communism (Ekiert \& Hanson, 2003). All these factors might also affect current levels of political participation. Yet, as Kitschelt notes, there is a trade-off between causal depth and process tracing. The capacity to reconstruct micro-causal chains between the explanandum and the ultimate outcome becomes more difficult when looking for more profound causes (Kitschelt, 2003). Future research should continue exploring how different legacies have interacted to produce the current diversity of protest trajectories in the post-communist world. 


\section{References}

Arbeitskreis "Volkswirtschaftliche Gesamtrechnungen der Länder" (Ed.). (2018). Bruttoinlandsprodukt, Bruttowertschöpfung in den Ländern der Bundesrepublik Deutschland 1991 bis 2017. Stuttgart: Statistisches Landesamt Baden-Württemberg.

Barnes, S. H. (2006). The Changing Political Participation of Postcommunist Citizens. International fournal of Sociology, 36(2), 76-98. doi: 10.2753/IJS0020-7659360203

Bartels, L. M., \& Jackman, S. (2014). A Generational Model of Political Learning. Electoral Studies, 33, 7-18. doi: 10.1016/j.electstud.2013.06.004

Bayer, M., Bethke, F. S., \& Lambach, D. (2016). The Democratic Dividend of Nonviolent Resistance. Fournal of Peace Research, 53(6), 758-771. doi: 10.1177/0022343316658090

Bernhagen, P., \& Marsh, M. (2007). Voting and Protesting: Explaining Citizen Participation in Old and New European Democracies. Democratization, 14(1), 44-72. doi: 10.1080/ 13510340601024298

Boix, C., Miller, M., \& Rosato, S. (2013). A Complete Data Set of Political Regimes, 1800-2007. Comparative Political Studies, 46(12), 1523-1554. doi: 10.1177/0010414012463905

Bunce, V. J., \& Wolchik, S. L. (2011). Defeating Authoritarian Leaders in Postcommunist Countries. New York: Cambridge University Press.

Bútora, M., \& Bútorová, Z. (1999). Slovakia's Democratic Awakening. Fournal of Democracy, 10(1), 80-95. doi: 10.1353/jod.1999.0003

Caren, N., Ghoshal, R. A., \& Ribas, V. (2011). A Social Movement Generation: Cohort and Period Trends in Protest Attendance and Petition Signing. American Sociological Review, 76(1), 125-151. doi: 10.1177/0003122410395369

Chenoweth, E., \& Stephan, M. J. (2011). Why Civil Resistance Works: The Strategic Logic of Nonviolent Conflict. New York: Columbia University Press.

Dalton, R. J., van Sickle, A., \& Weldon, S. (2010). The Individual-Institutional Nexus of Protest Behaviour. British fournal of Political Science, 40(1), 51-73. doi: 10.1017/S000712340999038X

della Porta, D. (2016). Where Did the Revolution Go? Contentious Politics and the Quality of Democracy. New York: Cambridge University Press.

Ekiert, G. (2003). Patterns of Postcommunist Transformation in Central and Eastern Europe. In G. Ekiert \& S. E. Hanson (Eds.), Capitalism and Democracy in Eastern and Central Europe: Assessing the Legacy of Communist Rule (pp. 89-119). Cambridge: Cambridge University Press.

Ekiert, G., \& Hanson, S. E. (2003). Time, Space, and Institutional Change in Central and Eastern Europe. In G. Ekiert \& S. E. Hanson (Eds.), Capitalism and Democracy: Assessing the Legacy of Communist Rule (pp. 15-48). Cambrige: Cambridge University Press.

ESS. (2017). European Social Survey, Rounds 1-8 Data. Bergen: NSD - Norwegian Centre for Research Data, Data Archive and distributor of ESS data for ESS ERIC. 
EVS. (2015). European Values Study Longitudinal Data File 1981-2008, ZA4804 Data file, Version 3.0.0. Cologne: GESIS Data Archive.

Grasso, M. T. (2014). Age, Period and Cohort Analysis in a Comparative Context: Political Generations and Political Participation Repertoires in Western Europe. Electoral Studies, 33, 63-76. doi: 10.1016/j.electstud.2013.06.003

Hooghe, M., \& Quintelier, E. (2014). Political Participation in European Countries: The Effect of Authoritarian Rule, Corruption, Lack of Good Governance and Economic Downturn. Comparative European Politics, 12(2), 209-232. doi: 10.1057/cep.2013.3

Howard, M. M. (2003). The Weakness of Civil Society in Post-Communist Europe. Cambridge: Cambridge University Press.

Inglehart, R., \& Catterberg, G. (2002). Trends in Political Action: The Developmental Trend and the Post-Honeymoon Decline. International fournal of Comparative Sociology, 43(3-5), 300-316. doi: 10.1177/002071520204300305

Jennings, M. K. (1987). Residues of a Movement: The Aging of the American Protest Generation. American Political Science Review, 81(2), 367-382. doi: 10.2307/1961957

Joly, P. (2018). Generations and Protest in Eastern Germany: Between Revolution and Apathy. Comparative Sociology, 17(6), 704-737. doi: 10.1163/15691330-12341481

Kitschelt, H. (2003). Accounting for Postcommunist Regime Diversity: What Counts as a Good Cause? In G. Ekiert \& S. Hanson (Eds.), Capitalism and Democracy in Eastern and Central Europe: Assessing the Legacy of Communist Rule (pp. 49-86). Cambridge: Cambridge University Press.

Kostadinova, T., \& Power, T. J. (2007). Does Democratization Depress Participation? Voter Turnout in the Latin American and Eastern European Transitional Democracies. Political Research Quarterly, 60(3), 363-377. doi: 10.1177/1065912907304154

Kostelka, F. (2014). The State of Political Participation in Post-Communist Democracies: Low but Surprisingly Little Biased Citizen Engagement. Europe-Asia Studies, 66(6), 945-968. doi: 10.1080/09668136.2014.905386

Mannheim, K. (1952). The Problem of Generations. In P. Kecskemeti (Ed.), Essays on the Sociology of Knowledge (pp. 276-322). London: Routledge and Kegan Paul.

McAdam, D. (1999). The Biographical Impact of Activism. In M. Giugni, D. McAdam, \& C. Tilly (Eds.), How Social Movements Matter (pp. 117- 146). Minneapolis: University of Minnesota Press.

Meyer, D. S., \& Whittier, N. (1994). Social Movement Spillover. Social Problems, 41(2), 277-298. doi: $10.2307 / 3096934$

Neundorf, A., \& Smets, K. (2017). Political Socialization and the Making of Citizens. Retrieved from https://doi.org/10.1093/oxfordhb/9780199935307.013.98

Oesch, D. (2006a). Coming to Grips with a Changing Class Structure: An Analysis of Employment Stratification in Britain, Germany, Sweden and Switzerland. International Sociology, 21(2), 
263-288. doi: $10.1177 / 0268580906061379$

Oesch, D. (2006b). Redrawing the Class Map: Stratification and Institutions in Britain, Germany, Sweden and Switzerland. Houndmills, Basingstoke, Hampshire: Palgrave Macmillan.

Pop-Eleches, G., \& Tucker, J. A. (2011). Communism's Shadow: Postcommunist Legacies, Values, and Behavior. Comparative Politics, 43(4), 379-408. doi: 10.5129/001041511796301588

Pop-Eleches, G., \& Tucker, J. A. (2013). Associated with the Past? Communist Legacies and Civic Participation in Post-Communist Countries. East European Politics and Societies, 27(1), 4568. doi: $10.1177 / 0888325412465087$

Rose, R. (1995). Mobilizing Demobilized Voters in Post-Communist Societies. Party Politics, 1(4), 549-563. doi: 10.1177/1354068895001004007

Teorell, J. (2010). Determinants of Democratization: Explaining Regime Change in the World, 1972-2006. Cambridge: Cambridge University Press.

Van der Meer, T., Grotenhuis, M. T., \& Pelzer, B. (2010). Influential Cases in Multilevel Modeling: A Methodological Comment. American Sociological Review, 75(1), 173-178. doi: 10.1177/ 0003122409359166

Vráblíková, K. (2014). How Context Matters? Mobilization, Political Opportunity Structures, and Nonelectoral Political Participation in Old and New Democracies. Comparative Political Studies, 47(2), 203-229. doi: 10.1177/0010414013488538

World Bank. (2018). World Development Indicators. Retrieved from https : / / dat acatalog .worldbank.org/dataset/world-development-indicators 


\section{Tables}

Table 1: EVS fieldwork in Central and Eastern Europe

\begin{tabular}{lll}
\hline Country & First year of democracy & EVS data collection period \\
\hline Bulgaria & 1990 & $08-1990$ to $12-1991$ \\
Czech Republic & 1990 (Czechoslovakia) & $08-1991$ to $10-1991$ \\
Estonia & 1991 & $06-1990$ to $08-1990$ \\
Germany, East & 1990 (Unified Germany) & $05-1990$ to $06-1990$ \\
Hungary & 1990 & $05-1991$ to 06-1991 \\
Latvia & 1993 & $06-1990$ to $08-1990$ \\
Lithuania & 1992 & $06-1990$ to $08-1990$ \\
Poland & 1989 & $05-1990$ to $06-1990$ \\
Slovakia & 1990 (Czechoslovakia) & $08-1991$ to 09-1991 \\
Slovenia & 1991 & $02-1992$ to 02-1992 \\
\hline
\end{tabular}

Sources: Boix et al. 2013 and EVS 2015. 
Table 2: Multilevel Models of Protest: Attending a Lawful Demonstration

\begin{tabular}{|c|c|c|c|c|c|c|}
\hline & \multicolumn{2}{|c|}{ Model 1} & \multicolumn{2}{|c|}{ Model 2} & \multicolumn{2}{|c|}{ Model 3} \\
\hline & Coef. & SE & Coef. & SE & Coef. & SE \\
\hline \multicolumn{7}{|l|}{ Individual-level predictors } \\
\hline Women & $-0.14^{*}$ & $(0.06)$ & $-0.14^{*}$ & $(0.06)$ & $-0.14^{*}$ & $(0.06)$ \\
\hline Age, relative & -0.01 & $(0.01)$ & -0.01 & $(0.01)$ & -0.01 & $(0.01)$ \\
\hline \multicolumn{7}{|l|}{ Education, Low (ref.) } \\
\hline Middle & 0.03 & $(0.06)$ & 0.03 & $(0.06)$ & 0.03 & $(0.06)$ \\
\hline High & $0.46^{* * *}$ & $(0.06)$ & $0.46^{* * *}$ & $(0.06)$ & $0.45^{* * *}$ & $(0.06)$ \\
\hline Unemployed & $0.19^{+}$ & $(0.10)$ & $0.19^{+}$ & $(0.10)$ & $0.18^{+}$ & $(0.10)$ \\
\hline Union member & $0.73^{* * *}$ & $(0.10)$ & $0.73^{* * *}$ & $(0.10)$ & $0.73^{* * *}$ & $(0.10)$ \\
\hline Native & -0.04 & $(0.12)$ & -0.04 & $(0.12)$ & -0.04 & $(0.12)$ \\
\hline \multicolumn{7}{|l|}{ Town size, Home in countryside (ref.) } \\
\hline Country village & -0.09 & $(0.08)$ & -0.09 & $(0.08)$ & -0.09 & $(0.08)$ \\
\hline Town or small city & 0.10 & $(0.09)$ & 0.10 & $(0.09)$ & 0.10 & $(0.09)$ \\
\hline Outskirts of big city & $0.25^{*}$ & $(0.11)$ & $0.25^{*}$ & $(0.11)$ & $0.26^{*}$ & $(0.10)$ \\
\hline A big city & $0.61^{* * *}$ & $(0.10)$ & $0.61^{* * *}$ & $(0.10)$ & $0.61^{* * *}$ & $(0.10)$ \\
\hline \multicolumn{7}{|l|}{ Social class, Unskilled workers (ref.) } \\
\hline Skilled workers & $0.15^{*}$ & $(0.07)$ & $0.15^{*}$ & $(0.07)$ & $0.15^{*}$ & $(0.07)$ \\
\hline Small business owners & 0.11 & $(0.09)$ & 0.11 & $(0.09)$ & 0.11 & $(0.09)$ \\
\hline Low service class & $0.31^{* * *}$ & $(0.08)$ & $0.30^{* * *}$ & $(0.08)$ & $0.31^{* * *}$ & $(0.08)$ \\
\hline High service class & $0.22^{*}$ & $(0.08)$ & $0.22^{*}$ & $(0.08)$ & $0.22^{*}$ & $(0.08)$ \\
\hline \multicolumn{7}{|l|}{ Macro-level predictors } \\
\hline New democracy & -0.21 & $(0.53)$ & -0.02 & $(0.53)$ & -0.41 & $(0.68)$ \\
\hline Early exp. to protest & $4.56^{*}$ & $(1.94)$ & $4.56^{*}$ & $(1.94)$ & $4.15^{*}$ & $(1.94)$ \\
\hline New democracy x Early exp. to protest & -2.53 & $(2.02)$ & -3.45 & $(2.11)$ & -3.02 & $(2.12)$ \\
\hline Eastern Germany & & & 0.66 & $(0.40)$ & $0.77^{+}$ & $(0.45)$ \\
\hline Year & & & & & $0.02^{+}$ & $(0.01)$ \\
\hline Logged GDP/cap. (mean) & & & & & -0.48 & $(0.61)$ \\
\hline Logged GDP/cap. (diff.) & & & & & -0.37 & $(0.55)$ \\
\hline Intercept & $-4.41^{* * *}$ & $(0.50)$ & $-4.41^{* * *}$ & $(0.50)$ & -44.86 & $(28.47)$ \\
\hline Variance (countries) & 0.31 & $(0.09)$ & 0.30 & $(0.09)$ & 0.29 & $(0.09)$ \\
\hline Variance (country-waves) & 0.11 & $(0.03)$ & 0.11 & $(0.03)$ & 0.10 & $(0.03)$ \\
\hline $\mathrm{N}$ (countries) & 25 & & 25 & & 25 & \\
\hline $\mathrm{N}$ (country-waves) & 163 & & 163 & & 163 & \\
\hline $\mathrm{N}$ (individuals) & 43855 & & 43855 & & 43855 & \\
\hline
\end{tabular}

Note: Results with logit estimates and standard errors. The models incorporate available sample weights. Source: ESS 2017. 
Table 3: Multilevel Models of Protest: Signing a Petition

\begin{tabular}{|c|c|c|c|c|c|c|}
\hline & \multicolumn{2}{|c|}{ Model 4} & \multicolumn{2}{|c|}{ Model 5} & \multicolumn{2}{|c|}{ Model 6} \\
\hline & Coef. & SE & Coef. & SE & Coef. & SE \\
\hline \multicolumn{7}{|l|}{ Individual-level predictors } \\
\hline Women & $0.21^{* * *}$ & $(0.04)$ & $0.21^{* * *}$ & $(0.04)$ & $0.21^{* * *}$ & $(0.04)$ \\
\hline Age, relative & 0.01 & $(0.01)$ & 0.01 & $(0.01)$ & 0.01 & $(0.01)$ \\
\hline \multicolumn{7}{|l|}{ Education, Low (ref.) } \\
\hline Middle & $0.42^{* * *}$ & $(0.08)$ & $0.42^{* * *}$ & $(0.08)$ & $0.41^{* * *}$ & $(0.08)$ \\
\hline High & $0.75^{* * *}$ & $(0.09)$ & $0.75^{* * *}$ & $(0.09)$ & $0.75^{* * *}$ & $(0.09)$ \\
\hline Unemployed & -0.02 & $(0.07)$ & -0.02 & $(0.07)$ & -0.02 & $(0.07)$ \\
\hline Union member & $0.45^{* * *}$ & $(0.04)$ & $0.45^{* * *}$ & $(0.04)$ & $0.45^{* * *}$ & $(0.04)$ \\
\hline Native & $0.37^{* * *}$ & $(0.06)$ & $0.37^{* * *}$ & $(0.06)$ & $0.37^{* * *}$ & $(0.06)$ \\
\hline \multicolumn{7}{|l|}{ Town size, Home in countryside (ref.) } \\
\hline Country village & -0.07 & $(0.05)$ & -0.07 & $(0.05)$ & -0.07 & $(0.05)$ \\
\hline Town or small city & 0.01 & $(0.06)$ & 0.01 & $(0.06)$ & 0.01 & $(0.06)$ \\
\hline Outskirts of big city & 0.03 & $(0.09)$ & 0.03 & $(0.09)$ & 0.03 & $(0.09)$ \\
\hline A big city & $0.19^{*}$ & $(0.07)$ & $0.19^{*}$ & $(0.07)$ & $0.19^{* *}$ & $(0.07)$ \\
\hline \multicolumn{7}{|l|}{ Social class, Unskilled workers (ref.) } \\
\hline Skilled workers & $0.17^{* * *}$ & $(0.04)$ & $0.17^{* * *}$ & $(0.04)$ & $0.17^{* * *}$ & $(0.04)$ \\
\hline Small business owners & $0.32^{* * *}$ & $(0.07)$ & $0.32^{* * *}$ & $(0.07)$ & $0.32^{* * *}$ & $(0.07)$ \\
\hline Low service class & $0.42^{* * *}$ & $(0.07)$ & $0.42^{* * *}$ & $(0.07)$ & $0.42^{* * *}$ & $(0.07)$ \\
\hline High service class & $0.44^{* * *}$ & $(0.06)$ & $0.44^{* * *}$ & $(0.06)$ & $0.44^{* * *}$ & $(0.06)$ \\
\hline \multicolumn{7}{|l|}{ Macro-level predictors } \\
\hline New democracy & $-2.22^{* * *}$ & $(0.36)$ & $-1.99^{* * *}$ & $(0.38)$ & $-1.36^{*}$ & $(0.63)$ \\
\hline Early exp. to protest & -0.96 & $(1.13)$ & -0.95 & $(1.13)$ & -0.41 & $(1.26)$ \\
\hline New democracy x Early exp. to protest & $4.08^{* *}$ & $(1.32)$ & $2.96^{+}$ & $(1.49)$ & 2.17 & $(1.63)$ \\
\hline Eastern Germany & & & $0.80^{+}$ & $(0.41)$ & $0.73^{+}$ & $(0.38)$ \\
\hline Year & & & & & -0.00 & $(0.01)$ \\
\hline Logged GDP/cap. (mean) & & & & & 0.77 & $(0.53)$ \\
\hline Logged GDP/cap. (diff.) & & & & & 0.22 & $(0.50)$ \\
\hline Intercept & $-2.01^{* * *}$ & $(0.30)$ & $-2.01^{* * *}$ & $(0.30)$ & -7.95 & $(24.33)$ \\
\hline Variance (countries) & 0.16 & $(0.05)$ & 0.15 & $(0.06)$ & 0.14 & $(0.04)$ \\
\hline Variance (country-waves) & 0.07 & $(0.01)$ & 0.07 & $(0.01)$ & 0.07 & $(0.01)$ \\
\hline $\mathrm{N}$ (countries) & 25 & & 25 & & 25 & \\
\hline $\mathrm{N}$ (country-waves) & 163 & & 163 & & 163 & \\
\hline $\mathrm{N}$ (individuals) & 43775 & & 43775 & & 43775 & \\
\hline
\end{tabular}

Note: Results with logit estimates and standard errors. The models incorporate available sample weights. Source: ESS 2017. 
Table 4: Multilevel Models of Protest: Boycotting certain Products

\begin{tabular}{|c|c|c|c|c|c|c|}
\hline & \multicolumn{2}{|c|}{ Model 7} & \multicolumn{2}{|c|}{ Model 8} & \multicolumn{2}{|c|}{ Model 9} \\
\hline & Coef. & SE & Coef. & SE & Coef. & SE \\
\hline \multicolumn{7}{|l|}{ Individual-level predictors } \\
\hline Women & $0.09^{*}$ & $(0.04)$ & $0.09^{*}$ & $(0.04)$ & $0.09^{*}$ & $(0.04)$ \\
\hline Age, relative & -0.00 & $(0.01)$ & -0.00 & $(0.01)$ & -0.00 & $(0.01)$ \\
\hline \multicolumn{7}{|l|}{ Education, Low (ref.) } \\
\hline Middle & $0.49^{* * *}$ & $(0.06)$ & $0.50^{* * *}$ & $(0.06)$ & $0.49^{* * *}$ & $(0.06)$ \\
\hline High & $0.94^{* * *}$ & $(0.05)$ & $0.94^{* * *}$ & $(0.05)$ & $0.93^{* * *}$ & $(0.05)$ \\
\hline Unemployed & 0.01 & $(0.09)$ & 0.01 & $(0.09)$ & 0.01 & $(0.09)$ \\
\hline Union member & $0.32^{* * *}$ & $(0.05)$ & $0.32^{* * *}$ & $(0.05)$ & $0.32^{* * *}$ & $(0.05)$ \\
\hline Native & $0.27^{* * *}$ & $(0.07)$ & $0.27^{* * *}$ & $(0.07)$ & $0.27^{* * *}$ & $(0.07)$ \\
\hline \multicolumn{7}{|l|}{ Town size, Home in countryside (ref.) } \\
\hline Country village & -0.11 & $(0.10)$ & -0.11 & $(0.10)$ & -0.11 & $(0.10)$ \\
\hline Town or small city & 0.01 & $(0.10)$ & 0.01 & $(0.10)$ & 0.01 & $(0.10)$ \\
\hline Outskirts of big city & 0.13 & $(0.09)$ & 0.13 & $(0.09)$ & 0.14 & $(0.09)$ \\
\hline A big city & 0.19 & $(0.11)$ & 0.19 & $(0.11)$ & 0.19 & $(0.11)$ \\
\hline \multicolumn{7}{|l|}{ Social class, Unskilled workers (ref.) } \\
\hline Skilled workers & 0.09 & $(0.06)$ & 0.09 & $(0.06)$ & 0.09 & $(0.06)$ \\
\hline Small business owners & $0.52^{* * *}$ & $(0.10)$ & $0.52^{* * *}$ & $(0.10)$ & $0.52^{* * *}$ & $(0.10)$ \\
\hline Low service class & $0.42^{* * *}$ & $(0.07)$ & $0.42^{* * *}$ & $(0.07)$ & $0.42^{* * *}$ & $(0.07)$ \\
\hline High service class & $0.54^{* * *}$ & $(0.09)$ & $0.54^{* * *}$ & $(0.09)$ & $0.55^{* * *}$ & $(0.09)$ \\
\hline \multicolumn{7}{|l|}{ Macro-level predictors } \\
\hline New democracy & $-2.43^{* * *}$ & $(0.44)$ & $-2.13^{* * *}$ & $(0.42)$ & $-1.35^{+}$ & $(0.69)$ \\
\hline Early exp. to protest & -2.11 & $(1.72)$ & -2.10 & $(1.72)$ & -1.52 & $(1.88)$ \\
\hline New democracy x Early exp. to protest & $4.84^{*}$ & $(1.88)$ & $3.39^{+}$ & $(1.90)$ & 2.38 & $(2.07)$ \\
\hline Eastern Germany & & & $1.04^{*}$ & $(0.40)$ & $1.02^{*}$ & $(0.39)$ \\
\hline Year & & & & & $0.02^{*}$ & $(0.01)$ \\
\hline Logged GDP/cap. (mean) & & & & & 0.96 & $(0.64)$ \\
\hline Logged GDP/cap. (diff.) & & & & & 0.04 & $(0.39)$ \\
\hline Intercept & $-2.16^{* * *}$ & $(0.45)$ & $-2.16^{* * *}$ & $(0.45)$ & $-47.65^{*}$ & $(19.61)$ \\
\hline Variance (countries) & 0.28 & $(0.08)$ & 0.26 & $(0.08)$ & 0.24 & $(0.06)$ \\
\hline Variance (country-waves) & 0.05 & $(0.01)$ & 0.05 & $(0.01)$ & 0.04 & $(0.01)$ \\
\hline $\mathrm{N}$ (countries) & 25 & & 25 & & 25 & \\
\hline $\mathrm{N}$ (country-waves) & 163 & & 163 & & 163 & \\
\hline $\mathrm{N}$ (individuals) & 43767 & & 43767 & & 43767 & \\
\hline
\end{tabular}

Note: Results with logit estimates and standard errors. The models incorporate available sample weights. Source: ESS 2017. 


\section{Figures}

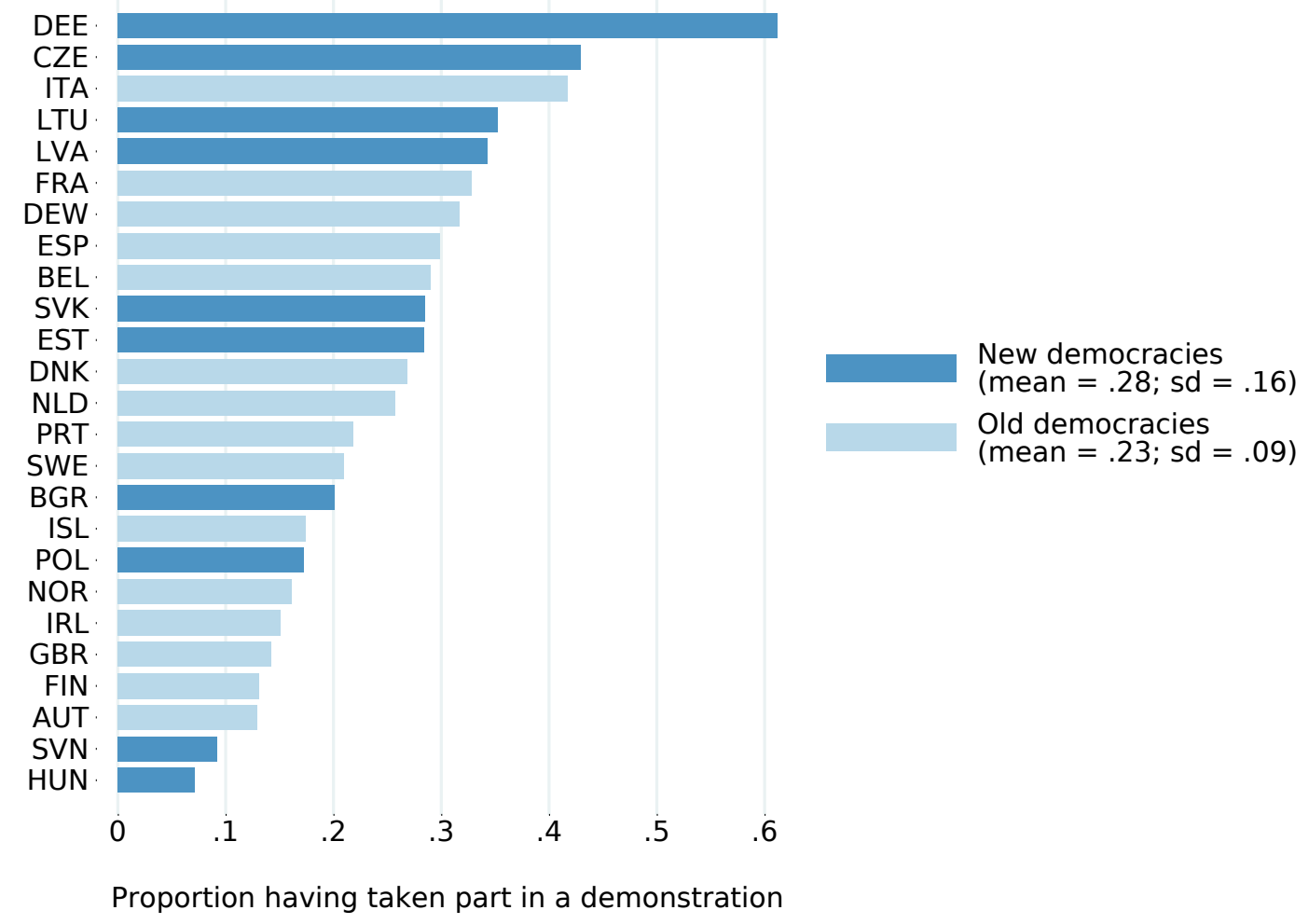

Figure 1: Protest experience of the 1989 generation as measured during the second wave of the European Values Study conducted between 1990 and 1993. Weighted results. Source: EVS 2015. 


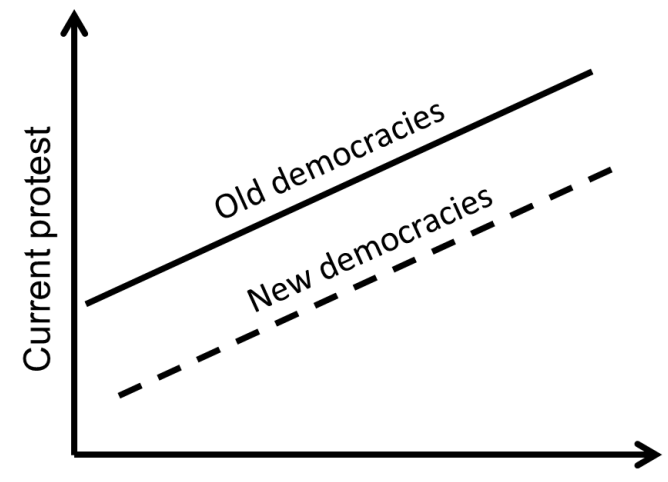

Early exposure to protest

(a) $H_{1}$ : Constant gap

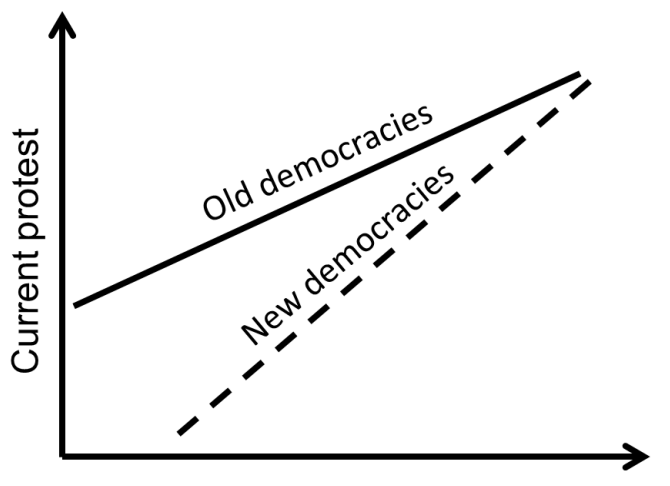

Early exposure to protest

(b) $\mathrm{H}_{2}$ : Moderation

Figure 2: The effect of early exposure to protest on the participation gap between old and new European democracies: two hypotheses.
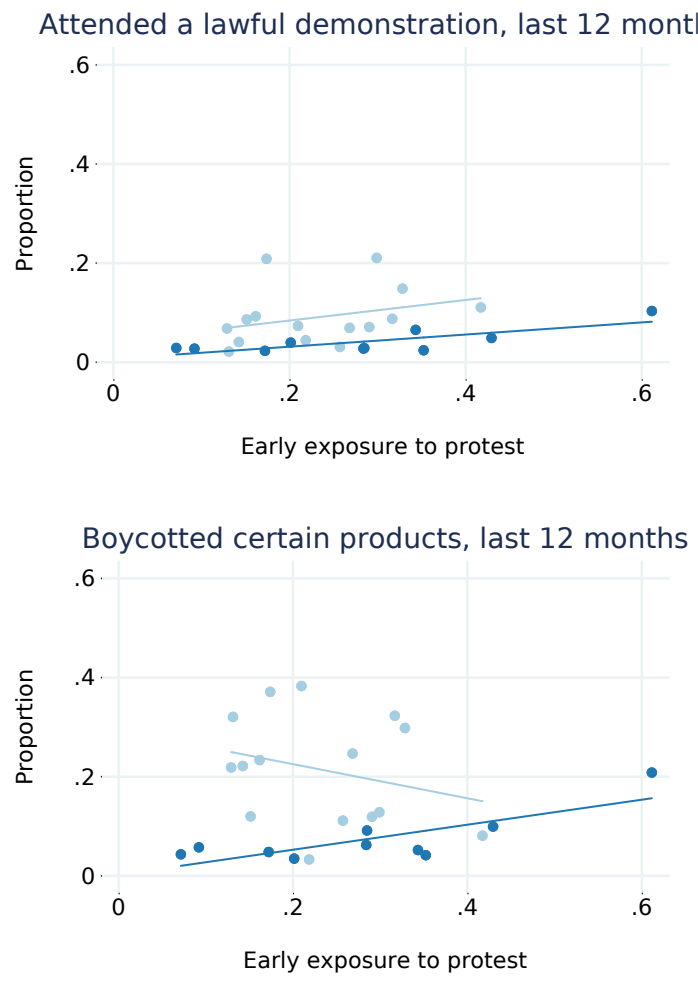

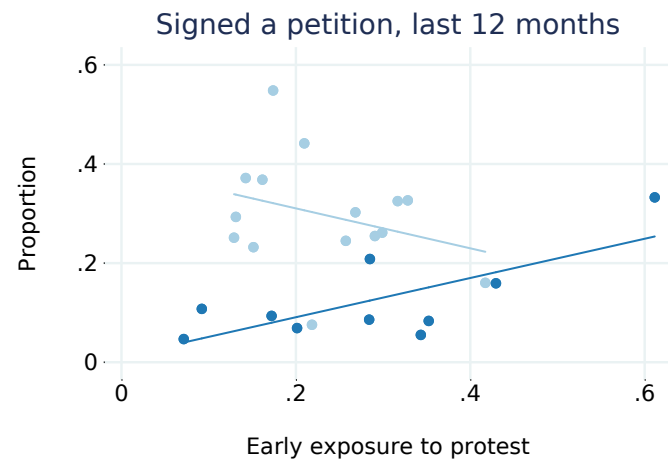

Early exposure to protest

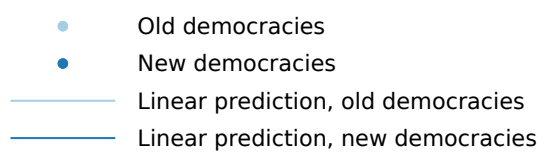

Figure 3: Annual participation in demonstrations, petitions, and boycotts (2002-2017) as a function of early exposure to protest (1990-1993), aggregated by country. Weighted results. Source: ESS 2017. 

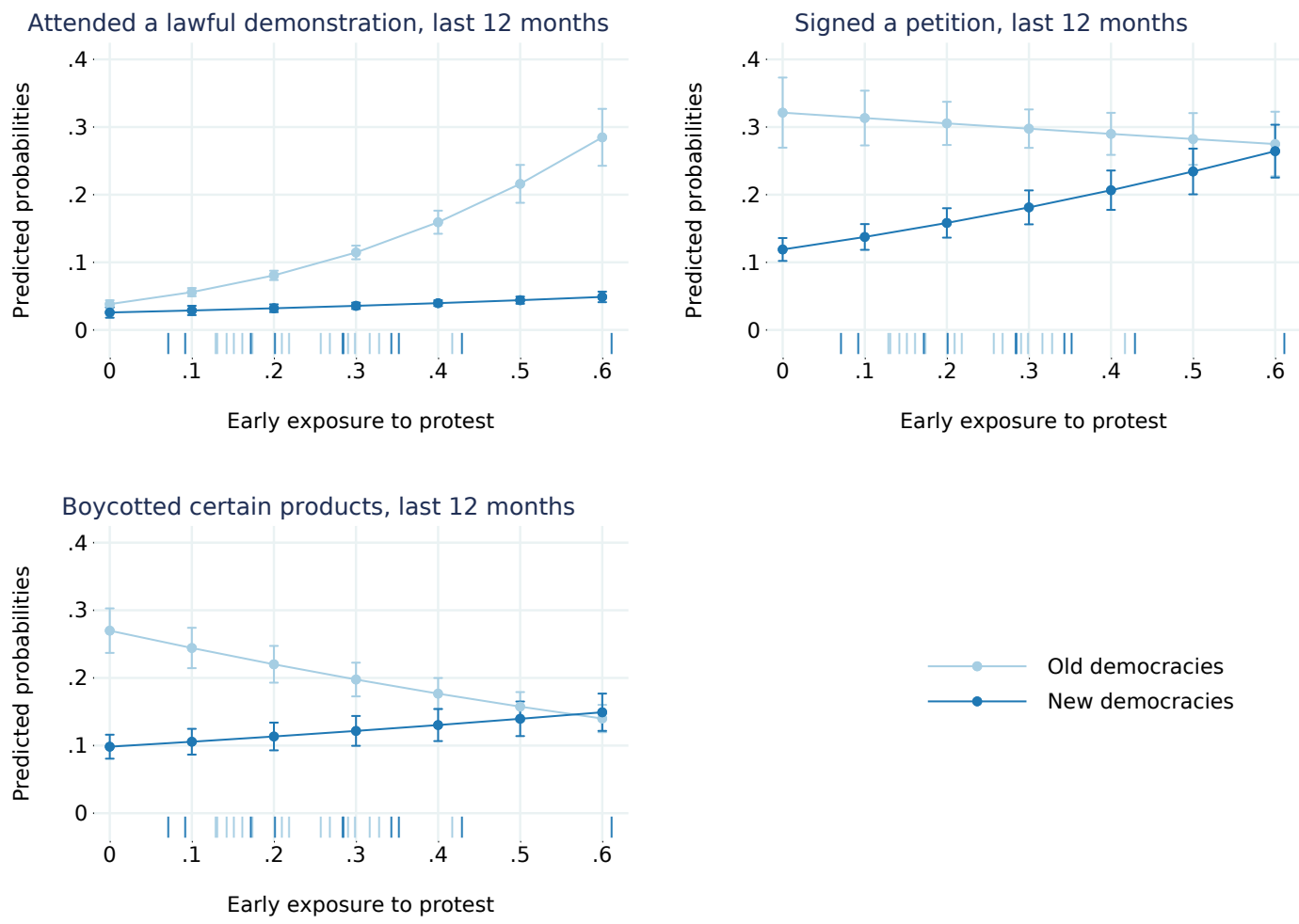

Figure 4: Predicted probabilities of having taken part in a protest activity in the 12 months preceding the survey, in new and old democracies, as a function of early exposure to protest (based on Models 3, 6, and 9). Source: ESS 2017. 